\title{
Analisis Efektivitas Aplikasi e-Batik Dalam Upaya Memperkenalkan Batik Indonesia Kepada Dunia
}

\author{
Anak Agung Ngurah Krisnanda Putra ${ }^{1}$, Wayan Suparta ${ }^{2, *}$ \\ ${ }^{1}$ Program Studi Informatika, Universitas Pembangunan Jaya \\ Tangerang Selatan, Banten 15413, Indonesia \\ krisnanda.putra@student.upj.ac.id \\ ${ }^{2}$ Program Studi Informatika, Universitas Pembangunan Jaya \\ Tangerang Selatan, Banten 15413, Indonesia \\ wayan.suparta@upj.ac.id
}

Received 28 Agust 2019, Revised 14 September 2019, Accepted 17 September 2019

\begin{abstract}
Batik is one of the identities owned by the Indonesians that has been recognized and established by UNESCO. This proves that batik has become one of the forms of Indonesian cultural wealth that must be preserved. To prevent the Indonesian culture is recognized by other countries, researchers made an application so-called e-Batik. In this study, testing and analysis were carried out to find out how effective the application of e-Batik was in introducing Indonesian batik to the world. For this purpose, researchers used quantitative research methods with data collection techniques by distributing questionnaires. Based on feedback from 33 respondents who were on average 17 to 20 years old and discussions that have been conducted, it can be concluded that the data obtained is proved to be valid and reliable so that the data can be trusted for use in research. Results showed that the highest value obtained from testing the effectiveness of e-Batik applications using a Likert scale was 96.212 and the lowest was 81.818 out of 100. This showed that e-Batik applications proved effective in introducing batik to the world.
\end{abstract}

Keywords: Batik, e-Batik, Survey, Application, Likert Scale

\begin{abstract}
Abstrak - Batik adalah salah satu identitas yang dimiliki oleh orang Indonesia yang telah diakui dan ditetapkan oleh UNESCO. Ini membuktikan bahwa batik sudah menjadi salah satu bentuk kekayaan budaya Indonesia yang harus dilestarikan. Untuk mencegah budaya Indonesia diakui oleh negara lain, peneliti ingin membuat aplikasi yang disebut e-Batik. Dalam penelitian ini, pengujian dan analisis dilakukan untuk mengetahui seberapa efektif aplikasi e-Batik dalam memperkenalkan batik Indonesia ke dunia. Untuk tujuan ini, peneliti menggunakan metode penelitian kuantitatif dengan teknik pengumpulan data dengan mendistribusikan kuesioner. Berdasarkan feedback dari 33 responden yang rata-rata berusia 17 hingga 20 tahun dan pembahasan yang telah dilakukan, dapat disimpulkan bahwa data yang diperoleh terbukti valid dan reliabel sehingga data tersebut dapat dipercaya untuk digunakan dalam penelitian. Hasil penelitian menunjukkan bahwa nilai tertinggi yang diperoleh dari pengujian efektivitas aplikasi e-Batik dengan menggunakan skala Likert adalah 96,212 dan terendah adalah 81,818 dari 100. Ini menunjukkan bahwa aplikasi e-Batik terbukti efektif dalam memperkenalkan batik ke dunia.

Kata Kunci: Batik, e-Batik, Survei, Aplikasi, Skala Likert
\end{abstract}

\section{PENDAHULUAN}

Indonesia merupakan negara kepulauan yang memiliki berbagai warisan budaya, seperti keris, wayang, angklung, tari saman, gamelan dan tidak terkecuali batik. Beberapa tahun lalu, muncul permasalahan mengenai batik yang diakui secara sepihak oleh Malaysia merupakan warisan budayanya (Lahitani, 2015). Mendengar hal tersebut, pemerintah Indonesia langsung bergerak cepat dengan mendaftarkan batik ke dalam jajaran daftar representatif budaya tak benda warisan manusia UNESCO pada tanggal 3 September 2008. Akhirnya UNESCO mengesahkan batik sebagai warisan budaya
Indonesia pada tanggal 2 Oktober 2009 dan menjadikan tanggal tersebut sebagai hari batik nasional.

Melihat permasalahan tersebut, perlu adanya suatu alat atau media yang dapat memberikan informasi mengenai batik Indonesia. Berdasarkan kasus yang terjadi di atas, peneliti akan membuat suatu aplikasi yang dapat mempermudah rakyat Indonesia bahkan seluruh dunia untuk mengetahui dan mempelajari secara detail mengenai ragam motif batik Indonesia yang jumlahnya melebihi 5,000 motif batik (Ridho, 2015). Aplikasi tersebut diberi nama eBatik. Sebelum membuat aplikasi tersebut, peneliti 
melakukan pengujian serta analisis terhadap aplikasi yang akan dibuat kepada masyarakat. Pengujian tersebut dilakukan untuk mengetahui apakah aplikasi tersebut dapat menjadi solusi untuk permasalahan yang sedang terjadi saat ini.

Pada era revolusi industri 4.0 saat ini, peran teknologi dan internet tidak terlepas dari kehidupan manusia, maka dari itu aplikasi ini dibuat untuk mempermudah setiap orang untuk mengetahui segala informasi mengenai batik mulai dari nama batik, jenis batik, asal batik hingga makna dari motif batik tersebut dengan hanya mengaksesnya melalui smartphone yang dimiliki oleh setiap orang. Aplikasi e-Batik ini diharapkan dapat menjadi media penyebaran informasi yang ramah lingkungan dan efektif agar dapat mempermudah setiap orang untuk mendapatkan informasi seputar batik Indonesia.

Dalam studi ini, kajian difokuskan kepada analisis pendapat masyarakat terhadap efektivitas aplikasi e-Batik yang akan dibuat oleh peneliti dalam memperkenalkan macam-macam batik Indonesia. Hasil analisis tersebut akan menjadi bahan pertimbangan untuk pembuatan aplikasi e-Batik. Tujuan dari penelitian ini adalah untuk menguji, meneliti, menganalisis dan mengetahui apakah aplikasi e-Batik tersebut dapat berfungsi seperti yang diharapkan.

\section{TINJAUAN PUSTAKA}

\section{Batik}

Berdasarkan etimologinya, batik berasal dari bahasa Jawa, yaitu "tik" yang berarti titik atau matik dan berkembang menjadi istilah "batik" hingga sampai saat ini (Prasetyo \& Singgih, 2016). Selain itu, batik juga mempunyai arti yang berhubungan dengan membuat titik atau meneteskan malam pada kain mori. Menurut Hanggopuro (2002), mulanya batik ditulis dengan kata "bathik". Hal tersebut mengacu pada penggunaan huruf Jawa "tha" bukannya "ta". Pemakaiaan bathik sebagai bentuk dari rangkaian titik tersebut sebenarnya kurang tepat karena berdasarkan etimologis, batik identik dikaitkan dengan suatu teknik atau proses penggambaran motif hingga tahap akhir, yaitu pelorodan. Salah satu yang menjadi ciri khas atau identitas dari batik adalah cara penggambaran motif pada kain melalui proses pemalaman. Proses pemalaman merupakan suatu proses menggoreskan cairan lilin yang ditempatkan pada wadah yang bernama canting.

Menurut Hamzuri (1985), batik merupakan suatu cara yang digunakan untuk memberi hiasan pada kain dengan cara menutupi bagian tertentu pada kain menggunakan perintang. Zat perintang yang sering digunakan adalah lilin atau malam. Kain yang sudah digambar dengan menggunakan malam kemudian diberi warna dengan cara pencelupan. Kemudian, malam dihilangkan dengan cara merebus kain. Akhirnya terbentuklah sehelai kain yang disebut batik yang memiliki berbagai motif dan sifat khususnya.
Berdasarkan motifnya, batik terbagi menjadi berbagai model, yaitu Batik Sudagaran, Batik Sida Luhur, Batik Kraton, Batik Petani, Batik Tambal, Batik Sida Mukti, Batik Sekar Jagad, Batik Pringgondani, Batik Cuwiri, Batik Semen Rama, Batik Kawung dan Batik Sida Asih. Motif batik adalah kerangka gambar yang mewujudkan batik secara keseluruhan. Batik juga memiliki berbagai macam motif antara lain motif manusia, hewan, tumbuhan, geometris, dan lain sebagainya. Terdapat lebih dari 5,000 motif batik yang telah diciptakan oleh para perajin dan seniman di Indonesia. Ribuan motif batik tersebut dapat dikelompokkan menjadi tujuh kelompok batik Indonesia, yaitu sebagai berikut (Presetyo \& Singgih, 2016).

1. Motif batik Parang. Motif batik ini memiliki filofosi yang cukup mendalam, yaitu berupa nasihat agar tidak pernah menyerah seperti ombak laut yang tak pernah berhenti bergerak. Batik ini juga menggambarkan hubungan yang tidak akan terputus sampai kapanpun, baik dalam arti upaya untuk memperbaiki diri, memperjuangkan kesejahteraan, ataupun bentuk pertalian kekeluargaan. Contoh dari motif batik Parang adalah Parang Klitik dan Parang Rusak;

2. Motif batik Geometris. Motif batik ini adalah motif batik yang motifnya tersusun secara geometris. Contohnya seperti Limaran, Gambir Saketi, Tirta Reja dan Sriwedari;

3. Motif batik Banji. Motif batik ini memiliki makna keteraturan dalam kehidupan atau kunci perhiasan yang terkunci rapat. Contoh darimotif batik ini adalah motif batik Banji Bengkok;

4. Motif batik tumbuh-tumbuhan menjalar. Motif ini memiliki makna kesinambungan dan keharmonisan antara manusia dan alam. Contoh dari motif batik ini, yaitu Semen Yogya, Luwung Klewer dan Cokrak-cakrik;

5. Motif batik tumbuh-tumbuhan air. Motif ini menggambarkan peran tumbuhan air dalam kehidupan manusia, contohnya adalah Ganggong dan Ganggong Sari;

6. Motif batik bunga. Motif bunga dan daun secara sederhana memiliki arti suatu kebahagiaan, keindahan dan juga kecantikan. Motif ini juga dapat diartikan sebagai wahyu Tuhan untuk mencapai suatu cita-cita, seperti penghargaan, kenaikan pangkat, rezeki yang berlimpah ataupun kehidupan yang baik. Contoh dari motif batik ini adalah Kembang Kenikir dan Truntum;

7. Motif batik satwa atau hewan. Motif batik ini merupakan bentuk gambaran motif yang terinspirasi dari hewan-hewan tertentu. Figurfigur hewan yang terletak pada batik ini memiliki makna yang cukup dalam dan berbeda-beda. Sebagai contoh, yaitu figur gajah yang memiliki arti kekuatan yang besar, figur burung yang menggambarkan suatu kebebasan dan lain sebagainya. Motif hewan yang sering digunakan sebagai objek dalam ragam hias batik ini adalah 
burung, gajah, kadal, ikan dan kupu-kupu. Contohnya adalah Gringsing dan Sido Mukti.

\section{Aplikasi}

Menurut Marjito (2016), aplikasi umumnya berupa perangkat lunak (software) adalah sebuah program yang siap digunakan untuk melaksanakan suatu fungsi bagi pengguna jasa aplikasi serta penggunaan aplikasi lain yang dapat digunakan oleh suatu sasaran yang akan dituju. Menurut kamus komputer eksekutif, aplikasi mempunyai arti pemecahan masalah yang menggunakan teknik pemrosesan data aplikasi yang biasanya mengacu pada sebuah komputasi yang diinginkan atau diharapkan. Aplikasi juga mempunyai fungsi sebagai pelayan kebutuhan beberapa akivitas yang dilakukan oleh manusia, seperti sistem jual beli yang terdapat di toko, permainan atau game online yang biasanya dimainkan oleh anak-anak, pelayanan masyarakat dan hampir semua kegiatan manusia dapat dibantu dengan adanya aplikasi.
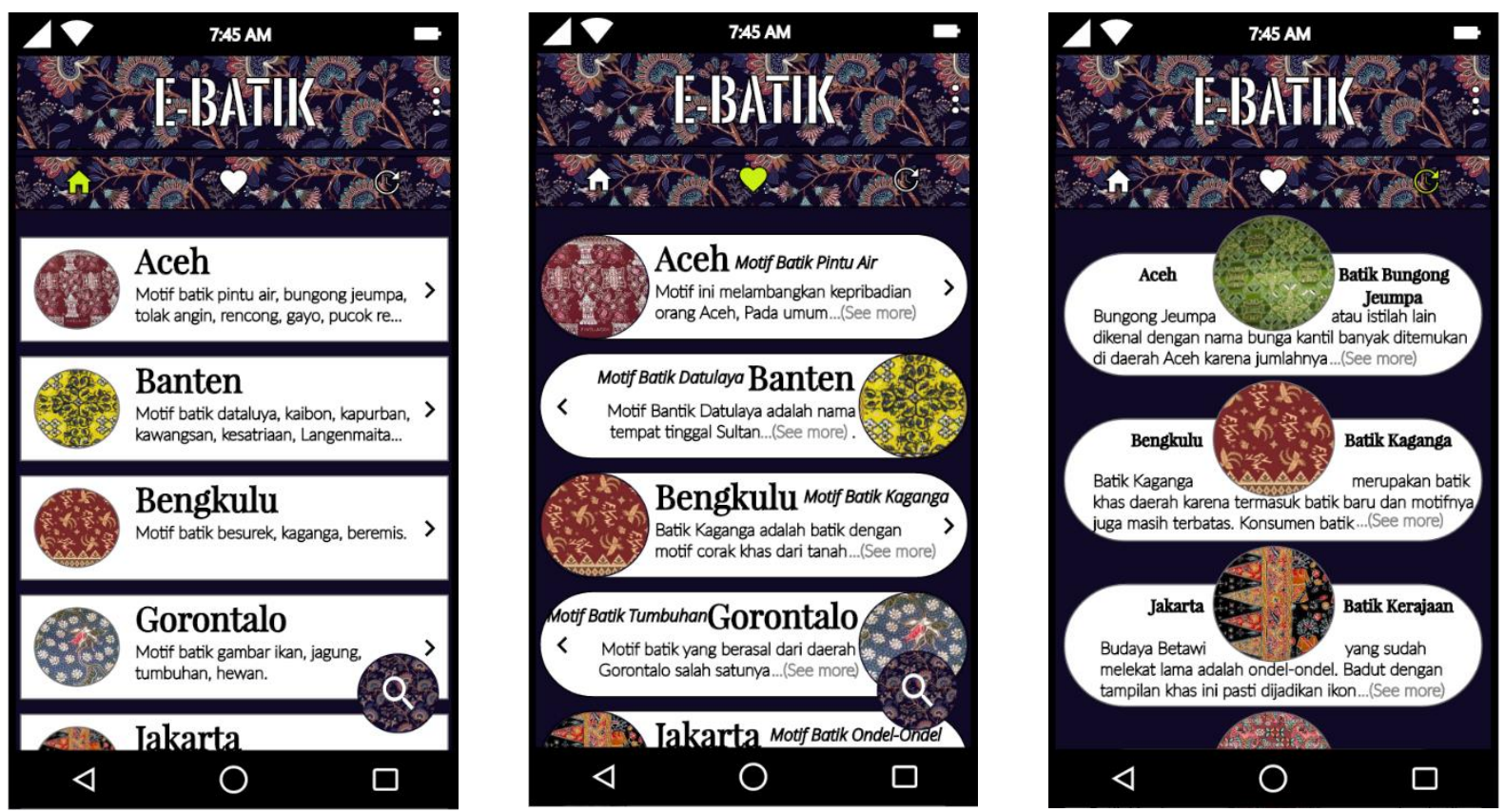

Gambar 1. Konsep aplikasi e-Batik
Pengertian aplikasi menurut para ahli adalah

1. Pengertian aplikasi menurut Kamus Besar Bahasa Indonesia (KBBI) adalah penerapan dari rancang sistem untuk mengolah suatu data yang menggunakan aturan atau ketentuan bahasa pemrograman tertentu. Aplikasi adalah suatu program komputer yang dibuat untuk mengerjakan dan melaksanakan tugas khusus yang diberikan oleh pengguna;

2. Menurut Abdurahman dan Riswaya (2014), aplikasi adalah program yang siap untuk digunakan dan dapat menjalankan berbagai perintah yang diberikan oleh pengguna dengan tujuan untuk mendapatkan hasil yang sesuai dengan tujuan dari dibuatnya aplikasi tersebut.

Konsep aplikasi e-Batik yang akan dibuat oleh peneliti dapat terlihat pada Gambar 1 dan 2 di bawah ini. sebagai berikut (Widarma \& Rahayu, 2017).
Pada Gambar 1, terdapat 3 bagian yang menjelaskan bahwa aplikasi ini terdiri dari 3 icon yang berada di bawah tulisan e-batik. 3 icon tersebut, yaitu icon halaman utama atau home ( ), ic on favorit ( ) dancicon rencent ( ). Jik@diklik, icon tersebut memiliki tampilan dan fungsi yang berbeda. Jika pengguna klik icon home, maka icon tersebut akan berwarna hijau yang menandakan bahwa pengguna berada di halaman tersebut. Halaman ini juga merupakan halaman utama yang pertama kali dilihat saat user membuka aplikasi ini. Pada halaman ini, peneliti mengelompokkan berbagai motif batik berdasarkan 34 provinsi yang ada di Indonesia dan disusun dari abjad a-z agar dapat mempermudah pengguna untuk mencari batik yang berasal dari provinsi tertentu.

Ketika pengguna klik icon berbentuk hati, maka icon tersebut juga akan berubah warna menjadi hijau yang menandakan pengguna sedang berada di halaman favorit. Di halaman ini, pengguna dapat menyimpan motif batik yang ingin dilihat kembali di lain waktu tanpa harus mencari dari awal.

Lalu terdapat icon recent yang berfungsi menampilkan motif batik yang baru dilihat oleh pengguna. Pada halaman ini, motif batik yang baru saja dilihat oleh pengguna akan tersimpan secara otomatis, tetapi tidak secara permanen. Jika pengguna lupa ingin menandakan motif batik yang sedang dilihat ke dalam halaman favorit, maka pengguna 
tidak harus mencari dari awal, tetapi dapat melihatnya di halaman ini.

Selain itu, terdapat juga tombol search (Q) yang posisinya berada di bawah kanan layar. Fungsi tombol search ini adalah untuk memudahkan pengguna mencari motif batik yang diinginkan dengan lebih cepat.

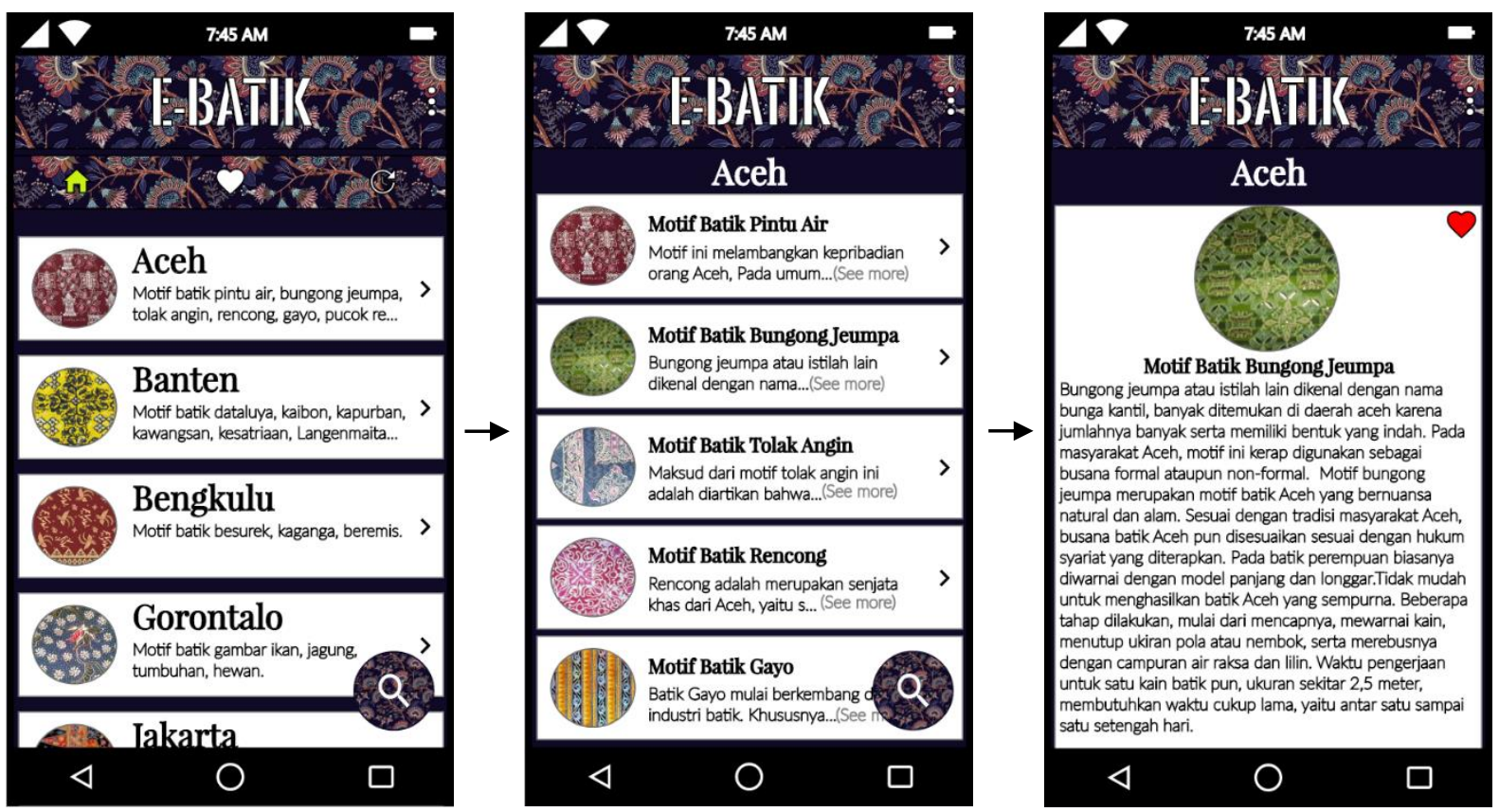

Gambar 2. Cara menggunakan aplikasi e-Batik

Pada Gambar 2, terdapat bagian yang menjelaskan cara penggunaan aplikasi e-Batik yang cukup mudah. Langkah-langkah dalam menggunakan aplikasi ini adalah sebagai berikut.

1. Pada halaman utama, pengguna aplikasi ini dapat memilih batik dari provinsi mana saja yang ada di Indonesia. Pada contoh di atas, pengguna memilih provinsi Aceh dengan menekan tulisan Aceh;

2. Lalu pengguna akan masuk ke halaman baru yang berisi berbagai macam motif batik yang berasal dari daerah Aceh. Pengguna dapat memilih motif batik daerah Aceh yang diinginkan di halaman tersebut. Pada contoh di atas, pengguna memilih motif batik Bungong Jeumpa dengan menekan tulisan tersebut;

3. Selanjutnya, pengguna akan masuk ke halaman penjelasan mengenai seputar motif batik Bungong Jeumpa;

4. Jika pengguna ingin menyimpan informasi mengenai motif batik tersebut, pengguna hanya mengklik icon hati yang terletak di atas sebelah kanan layar, lalu hati tersebut yang sebelumnya berwarna putih akan berubah menjadi warna merah seperti pada Gambar 2. Setelah mengklik icon tersebut, secara otomatis informasi mengenai motif batik tersebut akan tersimpan di halaman favorit.

\section{METODOLOGI PENELITIAN}

\section{Metode Penelitian}

Dalam penelitian ini, peneliti menggunakan metode kuantitatif. Metode kuantitatif merupakan metode yang digunakan untuk mengumpulkan data yang dapat diukur dengan angka. Selanjutnya data yang diperoleh akan diolah dengan menggunakan model teori, grafik, diagram maupun rumus matematika, sehingga dari data tersebut dapat diambil sebuah kesimpulan. Metode penelitian kuantitatif merupakan pendekatan untuk menguji teori objektif dengan menguji hubungan antar variabel. Variabel ini dapat diukur dengan menggunakan instrumen, sehingga jumlah data dapat dianalisis dengan menggunakan prosedur statistik (Wahidmurni, 2017).

\section{Metode Pengumpulan Data}

Pada penelitian ini, peneliti menggunakan metode penyebaran kuisioner untuk pengumpulan data mengenai efektivitas aplikasi yang akan dibuat, yaitu e-Batik dalam memperkenalkan corak batik Indonesia kepada dunia. Peneliti menyebarkan kuisioner yang terdiri dari 10 pernyataan kepada mahasiswa yang memiliki umur 17 hingga 20 tahun. Peneliti menggunakan model kuisioner tertutup dimana kuisioner yang telah tersedia jawabannya dan responden hanya memilih jawaban yang telah disediakan. Kuisioner yang telah dibuat oleh peneliti disebar menggunakan Google Form. Tujuan dibuat dan disebarkannya kuisioner ini adalah sebagai berikut. 
1. Mendapatkan data yang relevan dengan tujuan penelitian;

2. Mendapatkan realibilitas dan validitas yang signifikan dari data yang digunakan;

3. Menguji efektivitas dari aplikasi e-Batik berdasarkan jawaban responden.

Jika data dari penyebaran kuisioner tersebut sudah terkumpul, data tersebut akan langsung dianalisis untuk mengetahui apakah aplikasi e-Batik terbukti efektif dalam memperkenalkan batik ke seluruh dunia.

\section{Metode Analisis Data}

Metode analisis statistik deskriptif untuk mengetahui efektivitas aplikasi e-Batik dalam memperkenalkan batik kepada dunia adalah digunakan dalam pnelitian ini. Analisis statistik deskriptif merupakan teknik analisis yang dipakai untuk menganalisis data dengan mendeskripsikan atau menggambarkan data-data yang sudah dikumpulkan sebagaimana adanya.

\section{Alur Penelitian}

Tahapan penelitian yang dilakukan oleh peneliti dapat terlihat pada gambar 3 di bawah ini.

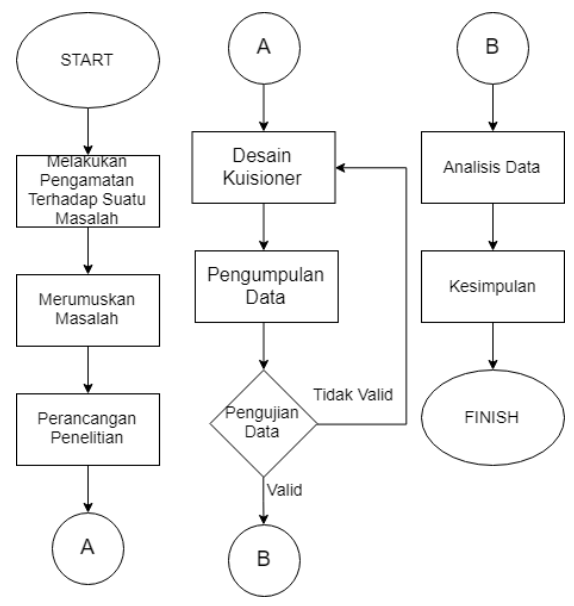

Gambar 3. Alur penelitian

Berdasarkan gambar di atas, tahap pertama yang dilakukan oleh peneliti adalah dengan mengamati suatu permasalahan tertentu, lalu merumuskannya. Kemudian, peneliti merancang penelitian dengan membuat kuisioner dan menyebarkannya dengan tujuan untuk mengumpulkan data sebagai bahan untuk melakukan penelitian. Setelah mendapatkan data dari hasil penyebaran kuisioner, data tersebut diuji validitasnya agar dapat digunakan sebagai bahan penelitian. Apabila data tersebut terbukti valid dan dapat digunakan, peneliti dapat menggunakan data tersebut untuk di analisis. Setelah selesai di analisis, peneliti menarik kesimpulan mengenai hasil penelitiannya terhadap permasalahan tertentu.

\section{HASIL DAN PEMBAHASAN}

\section{Rancangan Alat Ukur}

Peneliti melakukan pengumpulan data mengenai efektivitas aplikasi e-Batik dalam mengenalkan batik kepada dunia melalui Google Form. Peneliti memberikan 10 pernyataan, masing-masing memiliki empat pilihan dan bobot poin yang berbeda. Setiap responden bebas memilih pilihan yang sesuai dengan pendapatnya sendiri.

Peneliti selanjutnya melakukan pengujian validitas, realibilitas dan efektivitas dari kuisioner yang telah disebar kepada responden. Pengujian validitas merupakan langkah pengujian yang dilakukan terhadap suatu metode pengumpulan data yang memberikan pertanyaan maupun pernyataan dengan maksud untuk mengukur ketepatan kuisioner yang digunakan dalam proses penelitian, yaitu mengukur apa yang seharusnya diukur. Sedangkan uji realibilitas adalah salah satu metode dalam menganalisis data untuk mengukur konsistensi terhadap suatu data, jika dilakukan pengujian secara berulang-ulamg (Sujono \& Santoso, 2017).

Pengujian efektivitas penggunaan aplikasi eBatik dalam memperkenalkan batik Indonesia kepada dunia adalah menggunakan skala likert. Skala likert memiliki empat atau lebih pertanyaan maupun pernyataan yang dapat dipilih oleh responden yang masing-masing pilihan memiliki skor atau bobot poin yang dapat menggambarkan sifat atau pendapat dari responden tersebut. Pernyataan yang dapat dipilih oleh responden setiap soalnya, yaitu sangat setuju (4), setuju (3), tidak setuju (2) dan sangat tidak setuju (1). Skala likert adalah skala yang paling sering digunakan dalam melakukan riset berupa survey (Maryuliana, Ibnu \& Subroto, 2016).

Saat menanggapi pertanyaan dalam skala likert, responden menentukan tingkat persetujuan mereka terhadap suatu pernyataan dengan memilih salah satu dari pilihan yang tersedia. Untuk memperoleh skor dalam skala Likert dapat dilakukan dengan cara sebagai berikut.

Skor Akhir $=\frac{\text { Nilai } S D+\text { Nilai } C D+\text { Nilai } K D+\text { Nilai } S K D}{\text { nilai skala terbesar } \times \text { jumlah responden }} \times 100(1)$

dimana:

SD : Sangat Dibutuhkan/Sangat Setuju

CD : Cukup Dibutuhkan/Setuju

KD : Kurang Dibutuhkan/Kurang Setuju

SKD : Sangat Kurang Dibutuhkan/Sangat Tidak Setuju

Rumus untuk menghitung validitas setiap item dalam kuesioner dapat diberikan melalui rumus korelasi berikut.

$$
r_{X Y}=\frac{N \sum X Y-\sum X \sum Y}{\sqrt{\left(N \sum X^{2}-\left(\sum X\right)^{2}\right)\left(N \sum Y^{2}-\left(\sum Y\right)^{2}\right)}}
$$

dimana:

$\mathrm{r}_{\mathrm{xy}} \quad$ : Koofisien korelasi antara $\mathrm{X}$ dan $\mathrm{Y}$

$\sum \mathrm{X} \quad$ : Jumlah skor butir soal 
$\sum \mathrm{Y} \quad$ : Jumlah skor total soal

$\mathrm{N} \quad$ : Jumlah responden

Sementara rumus pengujian realibilitas dapat menggunakan Alpha Cronbach yaitu:

$$
\alpha=\frac{K}{K-1}\left[\frac{\sum s_{i}^{2}}{S_{T}^{2}}\right]
$$

dimana:

$$
\begin{array}{ll}
\alpha & \text { : Realibilitas instrumen } \\
\mathrm{K} & \text { : Jumlah item yang diuji } \\
\sum_{\mathrm{S}_{\mathrm{i}}{ }^{2}} & \text { : Jumlah varian tiap skor } \\
\mathrm{S}_{\mathrm{T}}{ }^{2} & \text { : Varian Total }
\end{array}
$$

\section{Uji Validitas}

Berdasarkan data yang telah didapatkan dari penyebaran kuisioner, terdapat 33 responden yang memberikan jawabannya. Dari data tersebut, dapat diketahui persentase jawaban setiap itemnya. Selanjutnya, peneliti melakukan pengujian validitas dan mendapatkan hasil bahwa dari 10 soal yang telah dibuat, terdapat 9 soal valid dan 1 soal tidak valid.

Menurut Sujono dan Santoso (2017), banyaknya pertanyaan yang berkorelasi dengan nilai keseluruhan memperlihatkan bahwa pertanyaan tersebut dapat memberikan dukungan terhadap apa yang sedang diteliti. Kriteria pengujian ialah:

a) Jika nilai $t$ hitung lebih besar atau sama dengan $t$ tabel (dengan taraf signifikansinya 5\%) maka hasil pengujian validitas terhadap soal tersebut dapat dinyatakan valid.

b) Jika nilai perhitungan $t$ hitung kurang dari $t$ tabel (dengan taraf signifikansinya 5\%) maka hasi pengujian validitas terhadap soal tersebut dapat dinyatakan tidak valid.

Tabel 1 menunjukkan hasil uji validitas dengan 33 data pada taraf signifikansinya 5\%. Pada Tabel 1 terlihat bahwa soal nomor satu terbukti tidak valid ( $t$ hitung < nilai $t$ tabel). Sedangkan soal lainnya mendapatkan hasil yang valid.

Tabel 1. Hasil uji validitas

\begin{tabular}{cccc}
\hline $\begin{array}{c}\text { Nomor } \\
\text { Item }\end{array}$ & $\boldsymbol{t}$ hitung & $\boldsymbol{t}$ tabel & $\begin{array}{c}\text { Hasil Uji } \\
\text { Validitas }\end{array}$ \\
\hline 1 & 1,722 & & Tidak Valid \\
2 & 5,837 & & Valid \\
3 & 5,438 & & Valid \\
4 & 7,559 & & Valid \\
5 & 9,479 & 2,040 & Valid \\
6 & 4,571 & & Valid \\
7 & 8,216 & & Valid \\
8 & 7,897 & & Valid \\
9 & 8,527 & & Valid \\
10 & 8,051 & & Valid \\
\hline
\end{tabular}

\section{Uji Realibilitas}

Pengujian realibilitas yang dilakukan dengan menggunakan pengujian Cronbach Alpha menghasilkan nilai 0,8854. Berdasarkan Tabel 2, angka tersebut membuktikan bahwa data kuisioner yang disebarkan oleh peneliti adalah berkorelasi Sangat Tinggi. Dengan itu, data hasil kuesioner atau angket dapat sepenuhnya dipercaya, artinya kuesioner yang dibuat sudah reliabel.

Tabel 2. Klasifikasi koefisien realibilitas tes (Nasir, 2015)

\begin{tabular}{cc}
\hline Realibilitas Tes $(\mathbf{r})$ & $\begin{array}{c}\text { Kategori Instrumen } \\
\text { Tes }\end{array}$ \\
\hline $0.00<\mathrm{r} \leq 0.20$ & Sangat Rendah \\
$0.20<\mathrm{r} \leq 0.40$ & Rendah \\
$0.40<\mathrm{r} \leq 0.60$ & Sedang \\
$0.60<\mathrm{r} \leq 0.70$ & Tinggi \\
$0.80<\mathrm{r} \leq 1.00$ & Sangat Tinggi \\
\hline
\end{tabular}

\section{Uji Efektivitas}

Pengujian efektivitas aplikasi e-Batik dilakukan dengan menggunakan skala likert. Tabel 3 menunjukkan skor kriterium hasil pengujian yang diperoleh dimana jumlah responden adalah 33 orang.

Tabel 3. Kriterium dan Rating Scale dari pendapat responden

\begin{tabular}{cccc}
\hline $\begin{array}{c}\text { Skala } \\
\text { Jawaban }\end{array}$ & $\begin{array}{c}\text { Nilai } \\
\text { Skala }\end{array}$ & $\begin{array}{c}\text { Skor } \\
\text { Kriterium }\end{array}$ & $\begin{array}{c}\text { Rating } \\
\text { Scale }\end{array}$ \\
\hline Sangat Setuju & 4 & 100 & $76-100$ \\
Setuju & 3 & 75 & $51-75$ \\
Tidak Setuju & 2 & 50 & $26-50$ \\
$\begin{array}{c}\text { Sangat Tidak } \\
\text { Setuju }\end{array}$ & 1 & 25 & $1-25$ \\
\hline
\end{tabular}

Berdasarkan rumus perhitungan, maka skala sangat setuju diperoleh skor kriterium 100 dan rating scale berkisar 76 - 100, setuju diperoleh skor kriterium 75 dan rating scale berkisar 51 - 75, tidak setuju diperoleh skor kriterium 50 dan rating scale berkisar $26-50$, sangat tidak setuju diperoleh skor kriterium 25 dan rating scale berkisar $1-25$.

Berdasarkan jawaban 33 responden terhadap 10 pernyataan pada kuisioner yang telah diberikan, didapatkan data bahwa jumlah bobot poin pilihan sangat setuju sebesar 640 , bobot poin pilihan setuju sebesar 471, bobot poin pilihan tidak setuju sebesar 26 dan bobot poin pilihan sangat tidak setuju sebesar 0 . Hasil perhitungan tersebut dapat terlihat pada Gambar 4 di bawah ini.

Setelah mendapatkan data $\mathrm{di}$ atas, peneliti melakukan pengujian frekuensi jawaban terhadap setiap pertanyaan pada kuisioner yang telah diberikan kepada responden. Perlu dicatat bahwa persepsi responden adalah kebetulan mewakili sebagian besar wilayah Indonesia. Dengan masifnya media massa 
online dan aplikasi online melalui sharing informasi maka sebaran responden secara tidak langsung akan merambah dunia. Dengan asumsi ini dan berdasarkan hasil analisis yang telah dilakukan dapat dinyatakan bahwa aplikasi e-Batik terbukti efektif sebagai satu media dalam memperkenalkan batik Indonesia ke seluruh dunia.



Gambar 4. Diagram jawaban terbanyak yang dipilih oleh responden

\section{KESIMPULAN DAN SARAN}

Berdasarkan hasil analisis dan pengujian yang telah dilakukan dengan menyebar kuisioner dan konsep aplikasi e-Batik kepada responden, terbukti bahwa aplikasi e-Batik efektif dalam memperkenalkan batik kepada dunia. Hal tersebut dapat dibuktikan setelah peneliti melakukan pengujian validitas dan realibilitas terhadap 33 data responden yang didapatkan dari penyebaran kuisioner. Berdasarkan hasil pengujian validitas dan realibilitas menggunakan skala likert, data yang diperoleh dari kuisioner tersebut sudah reliabel dan dapat dipercaya, sehingga data tersebut dapat digunakan untuk menghitung efektivitas aplikasi ebatik dalam memperkenalkan batik kepada dunia. Hasil perhitungan efektivitas menggunakan skala likert membuktikan bahwa aplikasi e-batik dapat menjadi media pengenalan batik yang efektif dan dapat mengatasi permasalahan mengenai pengakuan budaya Indonesia, khususnya batik oleh negara lain.

Untuk memperoleh jangkauan persepsi yang luas terhadap batik Indonesia, penyebaran kuisioner akan diperbanyak (misalnya 100 responden dari beragam masyarakat dan negara) dan waktu pengumpulan data juga diperpanjang (misalnya 3 hingga 6 bulan). Penelitian lanjutan ini bermaksud ingin memperoleh hasil yang lebih baik dari hasil yang disajikan saat ini. Namun penelitian awal ini dapat menjadi dasar untuk kekuatan analisa dan dampaknya di masa depan.

\section{DAFTAR PUSTAKA}

Abdurahman, H. \& Riswaya, A. R. (2014), Aplikasi Pinjaman Pembayaran Secara Kredit pada Bank Yudha Bhakti. Jurnal Computech \& Bisnis, 8(2), 2442-4943.
Hamzuri, (1985), Batik blasik (Classical Batik). Jakarta: Djambatan.

Honggopuro, K. (2002), Batik sebagai busana dalam tatanan dan tuntunan. Yayasan Peduli Keraton.

Lahitani, S. (2015). 8 Warisan budaya Indonesia yang pernah diklaim Malaysia. Liputan 6, diakses dari https://www.liputan6.com/citizen6/read/2156339/8warisan-budaya-indonesia-yang-pernah-diklaimmalaysia [27 April 2019].

Marjito \& Tesaria, G. (2016). Aplikasi penjualan online berbasis android (studi kasus: di toko hoax merch). Jurnal Computech Dan Bisnis, 10(1), 40-49.

Maryuliana, Ibnu, Subroto, I. M., Chairul \& Haviana, S. F. (2016). Sistem informasi angket pengukuran skala kebutuhan materi pembelajaran tambahan sebagai pendukung pengambilan keputusan di sekolah menengah atas menggunakan skala likert. Jurnal Transistor Elektro dan Informatika. 1(2), 1-12.

Nasir, M. (2015). Analisis empirik program analisis butir soal dalam rangka menghasilkan soal yang baik dan bermutu sebagai alat evaluasi pembelajaran fisika. Prosiding Semirata 2015 bidang MIPA BKS-PTN Barat, pp. 336-347.

Prasetyo, A. \& Singgih. (2016). Karakteristik motif batik Kendal interpretasi dari wilayah dan letak geografis. Jurnal Imajinasi, 10(1), 52-60.

Ridho, P. R. (2015). Indonesia punya 5.849 motif batik. Beritagar.id, 2 Oktober 2015. Diakses dari https://beritagar.id/artikel/gaya-hidup/indonesiapunya-5849-motif-batik [28 April 2019].

Sujono \& Santoso, H. B. (2017) Analisis kualitas e-learning dalam pemanfaatan web conference metode webqual. Jurnal Sains Dan Teknologi, 9(2), 27-37.

Wahidmurni (2017). Pemaparan metode penelitian kuantitatif. UIN Maulana Malik Ibrahim Malang.

Widarma, A. \& Rahayu, S. (2017). Perancangan aplikasi gaji karyawan pada pt. pp london sumatra indonesia tbk. gunung malayu estate - kabupaten asahan. Jurnal Teknologi Informasi, 1(2), 166-173. 